\title{
Hemşirelik Öğrencilerinin Bakım Odaklı Hemşire-Hasta Etkileşimine Yönelik Tutum ve Davranışlarının Belirlenmesi
}

\author{
Mehtap Tan $\odot$, Hatice Polat $\odot$
}

Atatürk Üniversitesi, Hemşirelik Fakültesi, İç Hastalıkları Hemşireliği Anabilim Dalı, Erzurum, Türkiye

Mehtap Tan, Prof. Dr. Hatice Polat, Dr. Öğr. Üyesi

Iletişim:

Dr. Öğr. Üyesi Hatice Polat

Atatürk Üniversitesi, Hemşirelik Fakültesi, İ̧ Hastalıkları Hemşireliği Anabilim Dalı, Erzurum, Türkiye

Tel: +904422315791

E-Posta: haticepolat@atauni.edu.tr
Gönderilme Tarihi : 31 0cak 2019

Revizyon Tarihi : 20 Şubat 2019

Kabul Tarihi : 05 Mart 2019
ÖZET

Amaç: Bu çalışmada öğrenci hemşirelerin bakım odaklı hemşire-hasta arasındaki iletişimine yönelik tutum ve davranışlarının belirlenmesi amaçlanmıştır.

Gereç ve Yöntem: Araştırma 14-31 Aralık 2015 tarihleri arasında ikinci sınıf hemşirelik öğrencileri ile tanımlayıcı olarak yapıldı. Araştırmanın evrenini üç şubede öğrenim gören öğrenciler, örneklemini ise araştırmaya katılmaya gönüllü 176 öğrenci oluşturdu. Verilerin toplanmasında tanıtıc form ve "Bakım Odaklı Hemşire Hasta Etkileşimi Ölçeği" kullanıldı. Veriler SPSS programı ile sayı, yüzde, ortalama, standart sapma, t-test ve KW testleri kullanılarak değerlendirildi.

Bulgular: Öğrencilerin bakım odaklı hemşire-hasta etkileşim ölçek puan ortalamaları incelendiğinde; "önemlilik" puan ortalaması $295,48 \pm 49,64$, yeterlilik puan ortalaması $252,75 \pm 49,05$, uygulanabilirlik puan ortalaması $250,45 \pm 50,04$ olarak belirlendi. Öğrencilerin ölçeğin önemlilik, yeterlilik ve uygulanabilirlik boyutundan aldığı en yüksek puanın "gereksinimler" alt boyutunun olduğu, en düşük puanın ise "sorun çözme" alt boyutunun olduğu belirlendi. Sosyo-demografik özelliklere göre ölçek toplam puan ortalamaları incelendiğinde; yaş ile bakım odaklı hasta-hemşire etkileşimin önemlilik, yeterlilik ve uygulanabilirlik boyutu arasında ilişki olmadığı, cinsiyete göre önemlilik boyutu; hasta ile ilişkilerinde güçlük yaşama durumuna göre önemlilik boyutu; sosyal etkinlik durumuna göre önemlilik ve yeterlilik boyutu puan ortalamaları arasında anlamlı bir fark olduğu belirlendi.

Sonuç: Öğrencilerin bakım odaklı hemşire-hasta etkileşimlerine yönelik tutum ve davranışlarının olumlu yönde olduğu belirlendi. Cinsiyeti kadın olan, hasta ile iletişimde sorun yaşamayan ve sosyal etkinlik durumunu yeterli bulan öğrencilerin tutum ve davranışlarının daha olumlu olduğu belirlendi.

Anahtar sözcükler: Hemşire hasta ilişkisi, hemşirelik bakımı, hemşirelik öğrencileri, tutum

DETERMINATION OF ATTITUDES AND BEHAVIORS OF NURSING STUDENTS TOWARD CARE-FOCUSED NURSE-PATIENT INTERACTION

\section{ABSTRACT}

Purpose: The purpose of this study is to determine the attitudes and behaviors of nursing students towards care focused nursepatient interaction.

Material and Methods: The descriptive study was conducted with second-year nursing students between 14 and 31 December 2015. While the population of the study consisted of students studying in three branches, the sample consisted of the students who were voluntary to participate in the study. Information form and the "Caring Nurse-Patient Interaction Scale" were used to collect the data. The data were analyzed through the SPSS program and by using number, percentage, mean, standard deviation, t-test, and Kruskal-Wallis (KW).

Results: When examining the mean scores obtained by the students from the Caring Nurse-Patient Interaction Scale, it was determined that the mean score of "importance" was $295.48 \pm 49.64$, the mean score of "competence" was $252.75 \pm 49.05$, and the mean score of "feasibility" was $250.45 \pm 50.04$. While the highest score obtained by the students from "importance", "competence" and "feasibility" subscales was observed in the subscale of "requirements", the lowest score was observed in the subscale of "problem-solving". When examining total mean scores of the scale based on socio-demographic characteristics, it was determined that there was no correlation between age and the importance, competence and feasibility subscales of the caring nurse-patient interaction; and that there was a significant difference between the mean scores of the importance subscale and gender; between the mean scores of the importance subscale and having difficulties in patient relations; and between the mean scores of the importance and competence subscales and social activities.

Conclusion: It was found that the students had positive attitudes and behaviors toward the caring nurse-patient interactions. It was determined that the students who were female, did not experience any problem in communication with patients, and considered the status of social activity sufficient; had more positive attitudes and behaviors.

Keywords: Nurse patient relationship, nursing care, nursing students, attitude 
$\mathrm{H}$ emşirelik bireyin, ailenin ve toplumun sağlığını koruma, geliştirme ve hastalık durumunda rehabilitasyon uygulamalarını yapan bir meslek grubudur. Hemşireler bu uygulamaları yaparken iletişim becerilerini kullanarak problem çözme odaklı terapötik iletişimi kullanır (1).

Illetişim sözel ve sözel olmayan ifadelerin kullanıldığı bir süreçtir. Etkileşim en az iki kişinin, birbirini etkilediği ve birbirinden etkilendiği sözlü ve sözsüz yollarla iletişimde bulundukları durumdur (2). Bu etkileşim sürecinde, beden dilinin \%60', sesin \%30'u ve sözcüklerin ise sadece $\% 10$ 'u etkilidir. Hemşire hasta ile iletişim sürecinde kontrollü şekilde iletişim becerilerini kullanır ve hastanın da bunları kullanma durumunu değerlendirerek etkileşime girer (2-4).

Hemşirenin bütüncül yaklaşım ile bireyin sorunlarını belirleme ve çözüm bulma odaklı etkileşiminde hem hasta bireyin hem de hemşirenin tutumunu bazı faktörler etkileyebilmektedir. Hemşire-hasta etkileşiminde hemşirenin tutumunu terapötik iletişim becerileri, kişilerarası ilişki becerisi, bütüncül bakış açısı, profesyonel değerleri, zaman, çevresel şartlar ve ilişkisel faktörler etkiler. Hasta bireyin tutumunu ise fizyolojik, emosyonel ve bilişsel durumu, gelişimsel dönemi, değer ve inançları, kendini algılama ve özsaygı durumu etkiler $(2,3,5)$.

Etkileşim ve bakım ilişkisini inceleyen kuramcılar, Travelbee, Papleu ve King etkileşim sürecini basamaklar halinde inceleyen kuramlar geliştirmişlerdir. Aynı zamanda Orlando da hemşire hasta etkileşiminin önemini vurgulamıştır $(1,3,4,6)$. Watson'ın hemşire-hasta etkileşimine dayalı İnsan Bakım Teorisi; hemşirelerin sadece fiziksel değil, aynı zamanda sosyal, psikolojik, kültürel ve manevi boyutu ele alarak, holistik yaklaşıma dayalı bir model ile bakım verme sürecini tanımlar (7-9). Watson bu süreçte rol oynayan 10 faktör tanımlamıştır. Bu faktörler: insancılözgecil değerler sistemi; inanç ve umudun sürdürülmesi; kendine ve başkalarına duyarlııı; yardım etmek, bakım ilişkisine güvenmek; olumlu ve olumsuz duygu ve hislerin ifade edilmesini desteklemek ve onaylamak; yaratıcı, bireyselleştirilmiş problem olarak problemleri çözmek için bakım sürecine dahil olmak; bireye özgü öğretim ve öğrenme; zihinsel, fiziksel, sosyal ve manevi olarak destekleyici, koruyucu ve düzeltici çevrenin sağlanması; insan onurunu ve bütünlüğünü korurken temel insan gereksinimlerinin karşılanmasına yardım etmek; bakım ve iyileşmenin manevi boyutları ve varoluş fenomenolojisine açık olmaya izin verir (7). Cossette ve ark. (8) mevcut skalaları inceleyerek, Watson'un 10 iyileştirici faktörünün tümünü kapsayan bakım odaklı hemşire-hasta etkileşimi ölçeğini geliştirilmiştir. Böylece hemşire-hasta etkileşimine yönelik tutum ve davranışlar ölçülebilir hale getirilmiştir.

Bakım ilişkisini geliştiren iletişim teknikleri aktif dinleme, gözlemleri paylaşma, empati, umudun paylaşılması, mizah, dokunma, sessizlik, bilgi verme, açıklık getirme, odaklaşma, yansıtma, onaylama, ilişkili sorular sorma ile bireyi kabullendiğini, birey ile ilgilendiğini ve ona saygı duyduğunu ileterek bireyin duyduğu güveni arttırmakta bireyin kendisini ifade etmesine firsat vermektedir $(2,3,10)$.

Aynı zamanda kişiye ismi ile hitap etme, güç dağılımı, saygı, güven, girişkenlik, otonomi ve sorumluluk sahibi olmak gizlilik ve mahremiyete özen göstermekte önemli katkı sağlayacaktır $(2,3,11,12)$. Bütün bunları yaparken etik davranışı da sağlamalıdır.

Öğrenci hemşirelerin hasta ve hemşire etkileşimine yönelik tutum ve davranışlarının bilinmesi hemşirelik eğitiminde öğrencilerin kazanmış oldukları beceri ve tutumları değerlendirmede katkı sağlayacaktır. Bakım odaklı hasta-hemşire etkileşimine yönelik tutum ve davranışlarını belirlemeye yönelik farklı sınıflarda okuyan hemşirelik öğrencileri ile yapılan çalışmalar vardır $(11,13-17)$. Watson kuramında, medikal iyileştirici etkiden ziyade, hemşirenin bakım ve iyileştirici rollerini, doğru hasta bakımının yeni standartlarına dönüştürmeyi vurgular $(7,8)$. Bu araştırma öğrencilerin hemşire-hasta etkileşimine yönelik tutum ve davranışlarını belirlemek, ayrıca bu konuyla ilgili literatüre katkı sağlamak amacıyla yapılmıştır.

\section{Gereç ve Yöntem}

Araştırmanın türü

Bu araştırma tanımlayıcı olarak yapılmıştır.

Araştırmanın yapıldığı yer ve özellikleri

Araştırma Hemşirelik Fakültesi ikinci sınıf üniversite öğrencileri ile yapılmıştır. Fakültede 1, 2, 3 ve 4. Sını öğrencileri $A, B$ ve $C$ olmak üzere üç şube halinde eğitim görmektedir. Her bir şubede ortalama olarak 92 öğrenci bulunmaktadır.

\section{Araștırmanın evren ve örneklemi}

Araştırma 2015-2016 öğretim yılı güz döneminde, iç hastalıkları hemşireliği dersi kapsamında ilk kez hastalıklar ve tedavilerine ilişkin eğitim alan hemşirelik ikinci sınıf öğrencileri ile yapıldı. Araştırmanın evrenini üç şubede öğrenim gören ikinci sınıf öğrencileri (282), örneklemini ise araştırmaya katılmaya gönüllü öğrenciler oluşturdu. Araştırma, çalışmaya katılmayı kabul eden ve anket formlarını eksiksiz dolduran 176 (\%62) öğrenci ile tamamlandı. 
Verilerin toplanması

Araştırma verileri fakülte dersliklerinde 2015 Aralık ayında, anket formu ve Bakım Odaklı Hemşire Hasta Etkileşimi Ölçeği ile öğrencilere elden dağıtılarak araştırmacılar tarafından toplandı.

\section{Veri toplama araçları}

Verilerin toplanmasında öğrencileri tanıtıcı anket formu ve "Bakım Odaklı Hemşire Hasta Etkileşimi Ölçeği" kullanıldı;

Öğrencileri Tanıtıcı Form: Cinsiyet, yaş, mesleği seçme nedeni, hastalar ya da diğer insanlar ile sosyal ilişkilerinde zorluk yaşama ve mesleği seçme nedenini içeren 6 soru yer almaktadır.

\section{Bakım Odaklı Hemşire Hasta Etkileşimi Ölçeği} (BOHHEÖ): Cossette ve ark. (8) tarafından hemşirelerin bakıma ilişkin tutum ve davranışlarını değerlendirebilmek için, Watson'ın Bakım Kuramı temel alınarak geliştirilmiştir. Türkçe geçerlilik ve güvenirliği Atar ve Aştı (9) tarafından hemşire grubu ile yapılmıştır. İngilizce'den Türkçe'ye uyarlanan BOHHEÖ'nün geçerlik ve güvenirlik düzeyi yüksek bulunmuş olup, hemşirelere/hemşirelik öğrencilerine uygulanabileceği önerilmiştir (9). Ölçek 70 madde, üç alt boyut ve her bir alt boyutta bulunan on alt ölçekten oluşmaktadır. Likert tipi olan ölçekteki ifadeler 5, son derece; 4, çok; 3, orta derece; 2, biraz; 1 , hiç olarak derecelendirilir. Ölçekte bulunan maddelerin ne derecede önemli olduğu "önemlilik" alt boyutu, ne kadar yeterli olduğu "yeterlilik" alt boyutu, ne kadar uygulanabilir olduğu "uygulanabilirlik" alt boyutu ile değerlendirilir. Her bir alt boyutta bulunan on alt ölçek ise hümanizm, umut, duyarlılık, yardım edici ilişki, duyguların ifade edilmesi, sorun çözme, öğretim, çevre, gereksinimler ve maneviyat'tan oluşmaktadır. Alt ölçekler her bir boyut için aynı olup, ölçeğin aynı maddelerinden elde edilmektedir. Atar ve Aşti (9) ölçek maddelerinin ve alt ölçeklerin toplam ölçekle, maddelerin ait olduğu boyutla aynı amaca hizmet ettiğini saptamıştır. Ölçeğin üç boyutu için de toplam puan, tüm madde (70 madde) puanlarının toplanması ile elde edilir. Ölçeğin üç boyutu için alınabilecek en düşük puan 70, en yüksek puan 350'dir. Ölçekten alınan puanın artması, bakım odaklı hemşire-hasta etkileşimine ilişkin tutum ve davranışların olumlu yönde arttığını gösterir $(8,9)$. Ölçeğin Cronbach's alfa güvenirlik katsayısı önemlilik boyutu için 0,99, yeterlilik boyutu için 0,98, uygulanabilirlik boyutu için 0,99 olarak bulunmuştur (9). Bu araştırma için ölçeğin Cronbach's alfa güvenilirlik katsayısı değerleri önemlilik için 0,982, yeterlilik için 0,970, uygulanabilirlik için 0,984 olarak bulundu. Bu üç boyut için alt ölçek güvenilirlik katsayısı değerleri ise 0,574 ile 0,938 arasında değiştiği belirlendi.

\section{Verilerin analizi}

Veriler bilgisayar ortamında istatistik programı ile sayı, yüzde, ortalama, standart sapma, pearson correlation, t-test ve KW testleri kullanılarak yapıldı. Ölçek güvenilirliğini test etmek amacıyla Cronbach's alfa güvenilirlik katsayısı değeri hesaplandı. Verilerin normal dağılım gösterme durumuna göre parametrik ve non-parametrik testler kullanıldı.

\section{Araştırmanın etik yönü}

Araştırmanın yapıldığı kurumdan, Sağlık Bilimleri Fakültesi Etik Kurulundan (21.12.2015 tarih ve 32 sayılı), kullanılan ölçeğin geçerlilik ve güvenirliğini yapan araştırmacılardan izin alındı. Araştırmaya katılım için öğrencilerin yazılı ve sözlü katılım onayı ile gönüllülüğü esas alındı.

\section{Bulgular}

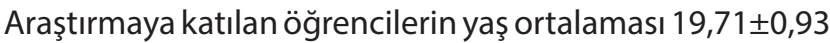
olduğu, \%79,5'inin cinsiyetinin kız olduğu belirlendi. Öğrencilerin, \%75,0'ının hasta ile iletişimde sorun yaşamadığı, \%84,7'sinin sosyal ilişkilerde güçlük yaşamadığı, \%36,9'unun mesleği kendi isteği/sevdiği için seçtiği belirlendi (Tablo 1).

Öğrencilerin bakım odaklı hemşire-hasta etkileşimine yönelik ölçeğin alt boyutlarına ait puan ortalamaları incelendiğinde; "önemlilik" puan ortalaması 295,48土49,64, yeterlilik puan ortalaması $252,75 \pm 49,05$, uygulanabilirlik puan

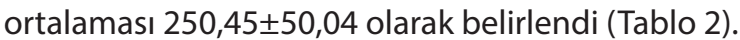

Öğrencilerin hemşire-hasta etkileşime yönelik tutum ve davranışları ölçeğinin önemlilik, yeterlilik ve uygulanabilirlik boyutundan aldığı en yüksek puanın "gereksinimler" alt ölçeğine ait olduğu belirlendi. En düşük puanın ise önemlilik ve uygulanabilirlik boyutu için "sorun çözme" iken, yeterlilik boyutunda "duyarlılık" alt ölçeğine ait olduğu belirlendi (Tablo 2).

Öğrencilerin yaş ortalamaları ile ölçeğin önemlilik, yeterlilik ve uygulanabilirlik alt boyutlarına ait puan ortalamaları arasındaki farkın istatistiksel olarak anlamsız olduğu saptandı ( $\mathrm{p}>0,05$, Tablo 1).

Araştırmaya katılan kız öğrencilerin ölçek alt boyutlarından aldıkları puan ortalamalarının erkek öğrencilerden daha yüksek olduğu belirlendi. Öğrencilerin cinsiyetleri 
ile ölçeğin uygulanabilirlik ve önemlilik alt boyutlarına ait puan ortalamaları arasındaki farkın istatistiksel olarak anlamlı olduğu bulunurken $(p<0,05)$, yeterlilik alt boyutu için aralarındaki farkın anlamlı olmadığı belirlendi $(p>0,05$, Tablo 1).

Hasta ile iletişimde sorun yaşamadığını belirten öğrencilerin ölçeğin alt boyutlarından aldıkları puan ortalamalarının, sorun yaşayan öğrencilere göre daha yüksek olduğu bulundu. Hasta ile iletişimde sorun yaşama durumu ile ölçek önemlilik alt boyutuna ait puan ortalaması arasındaki fark istatistiksel olarak anlamlı iken $(p<0,05)$, yeterlilik ve uygulanabilirlik alt boyutu için anlamlı olmadığı bulundu ( $p>0,05$, Tablo 1).

Sosyal ilişkilerde güçlük yaşayan ve yaşamayan öğrencilerin ölçek yeterlilik, uygulanabilirlik, önemlilik düzeyi alt boyutlarına ait puan ortalamaları arasındaki farkın istatistiksel olarak anlamsız olduğu saptandı ( $p>0,05$, Tablo 1 ).
Mesleği isteyerek/sevdiği için seçen öğrencilerin ölçek puan ortalamalarının aile isteği, iş imkanı ve diğer sebeplerle seçen öğrencilere göre daha yüksek olduğu belirlendi. Öğrencilerin mesleği seçme nedeni ile ölçeğin önemlilik, yeterlilik ve uygulanabilirlik alt boyutlarına ait puan ortalaması arasındaki farkın istatistiksel olarak anlamsız olduğu belirlendi ( $p>0,05$, Tablo 1).

\section{Tartışma}

Hemşirelikte bakım, hemşireliğin kuramsal bilgi içeriği ve uygulamalarının merkezinde yer alır (18). Hemşireliğin temel rollerinden olan bakım verme sürecinin gerçekleşmesi için hasta ile hemşire arasındaki etkileşimin önemli bir yeri vardır. Özellikle hemşirelik öğrencilerinde bu etkileşime yönelik tutum ve davranışların belirlenerek, gelişim süreçlerinin izlenmesi önemlidir. Bu araştırmada, ikinci sınıf hemşirelik öğrencilerinin bakım odaklı hemşire-hasta arasındaki iletişimine yönelik tutum ve davranışlarının belirlenerek ilgili literatür ile tartışılmıştır.

Tablo 1. Hemşirelik Öğrencilerinin tanımlayıcı özellikleri ve ölçek puan ortalamalarının dağıımı

\begin{tabular}{|c|c|c|c|c|}
\hline Değişkenler & $N(\%)$ & Önemlilik & Yeterlilik & Uygulanabilirlik \\
\hline Yaş ortalaması $19,71 \pm 0,93$ & & $r=-0,141 p=0,088$ & $r=0,23 p=0,784$ & $r=0,29 p=0,729$ \\
\hline \multicolumn{5}{|l|}{ Cinsiyet } \\
\hline $\mathrm{K} \mathrm{Iz}$ & $140(79,5)$ & $299,45 \pm 48,62$ & $256,51 \pm 49,18$ & $254,42 \pm 50,19$ \\
\hline \multirow[t]{2}{*}{ Erkek } & $36(20,5)$ & $278,50 \pm 51,28$ & $236,59 \pm 45,93$ & $233,86 \pm 46,67$ \\
\hline & & $\begin{array}{c}t: 2,032 \\
p=0,044\end{array}$ & $\begin{array}{c}t: 1,919 \\
p=0,057\end{array}$ & $\begin{array}{c}\mathrm{t}: 1,973 \\
\mathrm{p}=0,050\end{array}$ \\
\hline \multicolumn{5}{|l|}{ Hasta ile iletişimde sorun yaşama durumu } \\
\hline Evet & $6(3,4)$ & $237,50 \pm 45,43$ & $218,00 \pm 34,99$ & $236,16 \pm 39,87$ \\
\hline Hayır & $132(75,0)$ & $298,65 \pm 49,32$ & $255,47 \pm 52,31$ & $254,10 \pm 52,96$ \\
\hline \multirow[t]{2}{*}{ Kısmen } & $38(21,6)$ & $295,48 \pm 45,88$ & $250,19 \pm 36,54$ & $240,91 \pm 40,07$ \\
\hline & & $\begin{array}{c}\mathrm{KW}=7,203 \\
\mathrm{p}=0,028\end{array}$ & $\begin{array}{c}\mathrm{KW}=3,543 \\
\mathrm{p}=0,170\end{array}$ & $\begin{array}{c}K W=3,086 \\
p=0,214\end{array}$ \\
\hline \multicolumn{5}{|l|}{ Sosyal ilişkilerde güçlük yaşama durumu } \\
\hline Evet & $7(4,0)$ & $299,00 \pm 51,34$ & $237,57 \pm 48,47$ & $235,57 \pm 56,61$ \\
\hline Hayır & $149(84,7)$ & $297,32 \pm 49,99$ & $256,84 \pm 49,06$ & $253,87 \pm 50,06$ \\
\hline \multirow[t]{2}{*}{ Kısmen } & $20(11,4)$ & $277,03 \pm 44,94$ & $226,87 \pm 42,27$ & $230,87 \pm 43,99$ \\
\hline & & $\begin{array}{c}K W=3,115 \\
p=0,211\end{array}$ & $\begin{array}{c}K W=5,801 \\
p=0,055\end{array}$ & $\begin{array}{c}\mathrm{KW}=3,808 \\
\mathrm{p}=0,149\end{array}$ \\
\hline \multicolumn{5}{|l|}{ Mesleği seçme nedeni } \\
\hline Aile isteği & $26(14,8)$ & $297,95 \pm 50,52$ & $241,50 \pm 56,06$ & $238,60 \pm 59,73$ \\
\hline İş imkanı & $37(21,0)$ & $279,72 \pm 54,11$ & $241,68 \pm 43,71$ & $233,46 \pm 43,36$ \\
\hline Kendi isteği/sevdiği için & $65(36,9)$ & $302,26 \pm 41,65$ & $258,55 \pm 41,22$ & $259,70 \pm 43,37$ \\
\hline \multirow[t]{2}{*}{$\begin{array}{l}\text { Diğer (boş, nedensiz, bilmiyorum, puanım } \\
\text { uygun, tıp olmayınca) }\end{array}$} & $48(27,3)$ & $296,82 \pm 54,95$ & $253,57 \pm 56,43$ & $257,83 \pm 54,26$ \\
\hline & & $\begin{array}{c}K W=3,263 \\
p=0,353\end{array}$ & $\begin{array}{c}K W=3,562 \\
p=0,313\end{array}$ & $\begin{array}{c}\mathrm{KW}=6,239 \\
\mathrm{p}=0,101\end{array}$ \\
\hline
\end{tabular}


Araştırmada öğrencilerin bakım odaklı hemşire-hasta etkileşimine yönelik ölçek alt boyutlarına ait puan ortalamaları incelendiğinde; "önemlilik" puan ortalaması 295,48 $\pm 49,64$, "yeterlilik" puan ortalaması 252,75 $\pm 49,05$, "uygulanabilirlik" puan ortalaması $250,45 \pm 50,04$ olarak belirlendi (Tablo 2 ). Ölçekten alınabilecek en düşük puan 70 en yüksek puan ise 350'dir. Önemlilik, yeterlilik, uygulanabilirlik alt boyutlarına ait puan ortalamalarına göre araştırmaya katılan

Tablo 2. Öğrencilerin ölçek ve alt boyut puan ortalamaları

\begin{tabular}{|c|c|c|c|}
\hline Ölçek & $\begin{array}{c}\text { Ortalama } \\
\text { Standart sapma }\end{array}$ & $\begin{array}{l}\text { Madde puan } \\
\text { Standart sapma }\end{array}$ & $\begin{array}{l}\text { Minimum- } \\
\text { Maximum }\end{array}$ \\
\hline Önemlilik Boyutu & $295,48 \pm 49,64$ & $4,22 \pm 0,71$ & $70-350$ \\
\hline Hümanizm & $25,33 \pm 4,69$ & $4,22 \pm 0,78$ & $6-30$ \\
\hline Umut & $29,39 \pm 5,23$ & $4,19 \pm 0,75$ & $7-35$ \\
\hline Duyarlilık & $24,53 \pm 4,87$ & $4,09 \pm 0,81$ & $6-30$ \\
\hline Yardım edici ilişki & $29,11 \pm 5,63$ & $4,16 \pm 0,80$ & $7-35$ \\
\hline Duyguların ifade edilmesi & $24,88 \pm 4,56$ & $4,15 \pm 0,76$ & $6-30$ \\
\hline Sorun çözme & $24,49 \pm 4,81$ & $4,08 \pm 0,80$ & $6-30$ \\
\hline Öğretim & $37,79 \pm 6,56$ & $4,72 \pm 0,82$ & $9-45$ \\
\hline Çevre & $29,25 \pm 5,43$ & $4,18 \pm 0,78$ & $7-35$ \\
\hline Gereksinimler & $42,57 \pm 8,49$ & $4,26 \pm 0,84$ & $10-50$ \\
\hline Maneviyat & $24,85 \pm 5,24$ & $4,14 \pm 0,87$ & $6-30$ \\
\hline Yeterlilik Boyutu & $252,75 \pm 49,05$ & $3,61 \pm 0,70$ & $70-350$ \\
\hline Hümanizm & $21,89 \pm 6,30$ & $3,65 \pm 1,05$ & $6-30$ \\
\hline Umut & $24,63 \pm 4,73$ & $3,52 \pm 0,68$ & $7-35$ \\
\hline Duyarlılık & $20,62 \pm 4,16$ & $3,44 \pm 0,69$ & $6-30$ \\
\hline Yardım edici ilişki & $25,56 \pm 5,61$ & $3,65 \pm 0,80$ & $7-35$ \\
\hline Duyguların ifade edilmesi & $21,36 \pm 4,85$ & $3,56 \pm 0,81$ & $6-30$ \\
\hline Sorun çözme & $21,11 \pm 4,43$ & $3,52 \pm 0,74$ & $6-30$ \\
\hline Öğretim & $32,54 \pm 6,65$ & $4,07 \pm 0,83$ & $9-45$ \\
\hline Çevre & $25,60 \pm 7,23$ & $3,66 \pm 1,03$ & $7-35$ \\
\hline Gereksinimler & $36,66 \pm 8,02$ & $3,67 \pm 0,80$ & $10-50$ \\
\hline Maneviyat & $21,94 \pm 5,03$ & $3,66 \pm 0,84$ & $6-30$ \\
\hline Uygulanabilirlik Boyutu & $250,45 \pm 50,04$ & $3,58 \pm 0,71$ & $70-350$ \\
\hline Hümanizm & $21,52 \pm 4,82$ & $3,59 \pm 0,80$ & $6-30$ \\
\hline Umut & $24,40 \pm 5,30$ & $3,49 \pm 0,76$ & $7-35$ \\
\hline Duyarlillk & $20,75 \pm 4,75$ & $3,46 \pm 0,79$ & $6-30$ \\
\hline Yardım edici ilişki & $25,64 \pm 5,48$ & $3,66 \pm 0,78$ & $7-35$ \\
\hline Duyguların ifade edilmesi & $20,81 \pm 5,17$ & $3,47 \pm 0,86$ & $6-30$ \\
\hline Sorun çözme & $20,68 \pm 4,90$ & $3,45 \pm 0,82$ & $6-30$ \\
\hline Öğretim & $31,87 \pm 7,26$ & $3,98 \pm 0,91$ & $9-45$ \\
\hline Çevre & $25,15 \pm 5,92$ & $3,59 \pm 0,85$ & $7-35$ \\
\hline Gereksinimler & $36,14 \pm 8,42$ & $3,61 \pm 0,84$ & $10-50$ \\
\hline Maneviyat & $21,60 \pm 5,42$ & $3,60 \pm 0,90$ & $6-30$ \\
\hline
\end{tabular}

öğrencilerin bakım odaklı etkileşime yönelik tutum ve davranışlarının olumlu yönde olduğu şeklinde değerlendirilebilir. Öğrencilerin hemşire-hasta etkileşimine yönelik tutum ve davranışlarını belirlemeyle ilgili daha önce yapılan araştırmalarda önemlilik, yeterlilik ve uygulanabilirlik ölçek alt boyutlarına ait puan ortalamaları sırasıyla incelendiğinde; Zaybak ve ark. (13) araştırmasında 308,64 $\pm 43,32$,

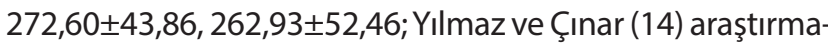
sında 326,56 $\pm 24,17,287,43 \pm 44,05,276,89 \pm 43,96$; Kalender ve ark. (15) araştırmasında 337,63 $\pm 23,18,293,41 \pm 34,99$, $290,85 \pm 42,11$ olup, öğrencilerin tutum ve davranışlarının olumlu yönde olduğunu bulmuşlardır.

Öğrencilerin ölçeğin alt boyutlarından aldıkları puan ortalamalarının karşılaştırmasında önemlilik alt boyutu puan ortalamalarının yeterlilik ve uygulanabilirlik boyutuna göre daha yüksek olduğu belirlendi. Kalender ve ark. (15) yapmış oldukları araştırma sonucunda ikinci sınıf öğrencilerin ölçeğin yeterlilik boyutuna ait puan ortalamasının yüksek olduğunu bulmuşlar. Daha önce yapılan bir araştırma sonucunda, ikinci sınıf öğrencilerinin hastaların mevcut sorunlarını anlamak, onlara yardım etmek için kendilerini yeterli görmeleri, hastaların duygularını rahatça ifade etmelerini beklemeleri, sorunlara yardımcı olmak istemeleri konusunda diğer sınıflardan daha başarılı oldukları, aynı zamanda ikinci sınıf öğrencilerinin almış oldukları derslerin de tutum ve davranışları etkileyebileceğini bulmuşlardır (15). Bu araştırmanın bulguları daha önce yapıIan araştırmaların sonuçlar ile uyumludur $(14,15)$. Bununla beraber daha önce yapılan araştırmaların sonuçlarında sınıflara göre ölçek alt boyutları puan ortalamaları arasında anlamlı bir farkın olmadığı da bulunmuştur $(13,16)$.

Araştırma sonucunda öğrencilerin yaşları ile ölçek alt boyutlarına ait puan ortalamaları arasında anlamlı bir ilişkinin olmadığı belirlendi. Daha önce sadece son sınıf öğrenciler ile yapılan bir araştırmada da yaş ile ölçek alt boyutları arasında anlamlı bir ilişkinin olmadığı belirlenmiştir (14). Araştırma sonuçlarındaki farklılığın öğrencilerin aralarındaki yaş farkının olmamasından kaynaklanabileceği düşünülmüştür. Zaybak ve ark. (13) 2., 3., ve 4. sınıf öğrencilerini kapsayan araştırmalarının sonucunda yaş ile önemlilik ve yeterlilik alt boyutu arasında negatif yönde zayıf bir ilişkinin olduğunu bulmuşlardır. Yaş ve ölçek puanları arasındaki ilişkinin aydınlatılmasına yönelik, yaş aralıkları fazla olan farklı örneklem grubunda çalışmalar yapılabilir.

Kız öğrencilerin önemlilik, yeterlilik ve uygulanabilirlik alt boyutuna ait puan ortalamalarının erkek öğrencilere göre daha yüksek olduğu bulundu. Zaybak ve ark. (13) yapmış 
oldukları araştırma sonucunda da ölçeğin önemlilik ve yeterlilik boyutuna ait puan ortalamaları kız öğrencilerde erkek öğrencilere göre daha yüksek olduğu bulunmuştur. Duru ve ark. (17) araştırmasında kız öğrencilerin önemlilik puan ortalamalarının daha yüksek olduğu belirlenmiştir. Cossette et al. (8) araştırmalarında benzer şekilde kız öğrencilere ait ölçek puan ortalamalarını erkek öğrencilere göre daha yüksek olarak bulmuşlardır. Daha önce yapılan çalışma sonuçlarında kız öğrencilerin kişilerarası iletişim becerilerinin erkeklere göre daha yüksek olduğu bulunmuştur (19-21). Kız öğrencilerin iletişim becerilerinin daha iyi olması çalışma sonucunu bu yönde etkilemiş olabileceği düşünülmüştür. Bununla beraber Arlı ve ark. (16), Yılmaz ve Çınar (14) ise cinsiyet ile ölçek puan ortalamaları arasında anlamlı bir farkın olmadığını belirtmişlerdir.

Hasta ile iletişimde güçlük yaşamayan öğrencilere ait tüm ölçek alt boyut puan ortalamaları hasta ile iletişimde güçlük yaşayan öğrencilere göre daha yüksek bulunmuştur. Bu araştırmanın sonucu daha önce yapılan araştırma sonucu ile uyumlu bulunmuştur (13). Bu çalışmanın sonucu hemşire-hasta ilişkisinin niteliğini belirleyen iletişim ve iletişim becerilerinin önemi, "hasta bakımının kalbi, hastanın iyileşmesinde anahtar" gibi kavramların tanımlarının yapıldığı literatür bilgisiyle de uyumlu bulunmuştur $(2,4,22)$.

Çalışma sonucunda sosyal ilişkilerde sorun yaşama durumuna göre öğrencilerin puan ortalamaları karşılaştırıldığında, sosyal ilişkilerde sorun yaşamayan öğrencilerin ölçek puan ortalamalarının daha yüksek olduğu bulundu. Zaybak ve ark. (13), Atar ve Aştı (11) araştırmalarında da benzer sonuçlara ulaşılmıştır. Literatürlerde de kişilerarası iletişim becerisi iyi olan hemşirelerin hasta-hemşire etkileşiminde daha başarılı olacağı bildirilmektedir $(2,9,13,23$, 24). Araştırma sonucunun literatür bilgisiyle uyumlu olduğu görülmüştür.

Araştırmaya katılan öğrencilerin mesleği seçme nedenine göre ölçek alt boyutu puan ortalamaları karşılaştırmasında

\section{Kaynaklar}

1. Velioğlu P, Pektekin Ç, Şanlı T. Hemşirelikte Kişilerarası İlişkiler. Açıköğretim Fakültesi Yayınları No: 226, Eskişehir: Anadolu Üniversitesi Yayınları No: 497, 1991. https://docplayer.biz. tr/52779921-Hemsirelikte-kisilerarasi-iliskiler-t-c-anadoluuniversitesi-yayinlari-no-497-acikogretim-fakultesi-yayinlarino-226.html

2. Yalçın Atar N, Atabek Aştı T. Hemşire Hasta Etkileşimi. IÜFN Hem Derg 2011;19:54-9.

3. Potter PA, Perry AG. Caring in nursing practice. Fundamentals of nursing. America: Mosby Inc.; 2005. pp.107-12. mesleği isteyerek/sevdiği için seçen öğrencilerin puan ortalamalarının daha yüksek olduğu belirlendi. Mesleği isteyerek seçmenin bakım odaklı hemşire-hasta etkileşimini olumlu yönde etkilemesi beklenen bir sonuçtur. Yapılan diğer araştırmalarda da mesleği isteyerek seçen öğrencilerin puan ortalamalarının yüksek olduğu bulunmuştur (13, 14). Literatürde de hemşirelik mesleğine ait becerilerin kazanılmasında, mesleğin profesyonel düzeyde sürdürülmesinde ve özgüven duygularının yükselmesinde mesleği severek yapmanın önemi vurgulanmıştır (25-28).

\section{Sonuç}

Araştırma sonucunda, öğrencilerin bakım odaklı hemşirehasta etkileşimine ait, önemlilik, yeterlilik ve uygulanabilirlik alt boyutlarına ilişkin tutum ve davranışlarının olumlu yönde olduğu belirlendi.

Kız öğrencilerin ve hasta ile iletişimde sorun yaşamayanların bakım odaklı hemşire-hasta etkileşimine ait, önemlilik alt boyutuna ilişkin tutum ve davranışlarının iyi düzeyde olduğu bulundu.

Hasta ile iletişimde sorun yaşamayanların, mesleği isteyerek/sevdiği için seçen öğrencilerin bakım odaklı hemşire hasta etkileşimine ait, önemlilik, yeterlilik ve uygulanabilirlik alt boyutlarına ilişkin tutum ve davranışlarının olumlu yönde olduğu belirlendi. Bu sonuçlar doğrultusunda;

- Hemşirelik öğrencilerinin mesleğe olan ilgisini/sevgisini/bağlılı̆̆ını teşvik etmek/artırmak için klinik eğiticiler tarafından desteklenmesi,

- Öğrenciler eğitim süreçlerinde hemşire hasta birey ile iletişimini etkileyebilecek faktörler konusunda bilgilendirmeye yönelik daha fazla desteklenmesi,

- Hemşire-hasta etkileşiminde bakım odaklı yaklaşımlarını belirlemeye, geliştirmeye yönelik araştırma ve uygulamaların yapılması önerilmektedir.

4. Özcan A. Hemşire-Hasta Illişkisi ve Illetişim 2. Basım. Ankara: Sistem Ofset; 2006.

5. Haworth SK, Dluhy NM. Holistic symptom management: Modelling the interaction phase. J Adv Nurs 2001;36:302-10. [CrossRef]

6. Birol L. Hemşirelik Süreci, 8. Baskı. İzmir: Etki Matbaacılık Yayıncılık Ltd. Şti; 2005. ss.54-95.

7. Gönen Şentürk S, Küçükgüçlü Ö, Watson J. Caring for caregivers of individuals with dementia: from the perspective of Watson's Theory of Human Caring. Hacettepe Üniversitesi Hemşirelik Fakültesi Derg 2017;4:62-72. http://www.hacettepehemsirelikdergisi.org/pdf/pdf_ HHD_231.pdf 
8. Cossette S, Caraa C, Ricarda N, Pepin J. Assessing nurse-patient interactions from a caring perspective: Report of the development and preliminary psychometric testing of the Caring Nurse-Patient Interactions Scale. Int J Nurs Stud 2005;42:673-86. [CrossRef]

9. Yalçın Atar NY, Atabek Aştı TA. Bakım odaklı hemşire-hasta etkileşimi ölçeğinin güvenirlik ve geçerliği. IÜFN Hem Derg 2012;20:129-39. https://pdfs.semanticscholar.org/8916/ d4391ad67c6f260269e98856799be1b21e71.pdf

10. Terakye G. Hasta-Hemşire Illişkileri 5. Basım, Ankara: Zirve Ofset; 1998. ss.33-133.

11. Brilowski GA, Wendler MC. An evolutionary concept analysis of caring. J Adv Nurs 2005;50:641-50. [CrossRef]

12. Neal K. Nurse-Patient Relationships. In: Hinchliff S, Norman S, Schober J, editors. Nursing Practice and Health Care, 4th ed. London: 2003.

13. Zaybak A, Günay İsmailoğlu E, Efteli E. Hemşirelik öğrencilerinin bakım odaklı hemşire-hasta etkileşimine yönelik tutum ve davranışları. Uluslararası Hakemli Hemşirelik Araştırmaları Derg 2014;1:24-37.

14. Yılmaz D, Çınar HG. Hemşirelik bölümü son sınıf öğrencilerinin bakım odaklı hemşire-hasta etkileşimine yönelik tutumlarının incelenmesi. Int J Hum Sci 2017;14:3300-9. [CrossRef]

15. Kalender N, Tosun N, Çınar FI, Bağçivan G, Yaşar Z. Hemşirelik yüksekokulu öğrencilerinin bakım odaklı hemşire-hasta etkileşimine yönelik tutum ve davranışlarının değerlendirilmesi. Gülhane Tıp Derg 2016;58:277-81.

16. Arlı SK, Bakan AB, Ozturk S, Erisik E, Yildirim Z. Critical thinking and caring in nursing students. Int J Caring Sci 2017;10:471-8. https://www.internationaljournalofcaringsciences.org/docs/51_ karadagarli_original_10_1.pdf

17. Duru P, Örsal Ö, Karadağ E. Bakım odaklı hemşire-hasta etkileşimi ile evde bakım hizmetleri tutumu arasındaki ilişkinin yapısal eşitlik modeli ile sınanması 17. Ulusal Halk Sağlığı Kongresi 20-24 Ekim 2014; Edirne. ss.1363-4.
18. Öner Altıok H, Şengün F, Üstün B. Bakım: Kavram analizi. DEÜHY ED 2011:4:137-40.

19. Bingöl G, Demir, A. Amasya sağlık yüksekokulu öğrencilerinin iletişim becerileri. Göztepe Tıp Derg 2011;26:152-9. [CrossRef]

20. Erigüç $G$, Şener $T$, Eriş $H$. İletişim becerilerinin değerlendirilmesi: bir meslek yüksekokulu öğrencileri örneği. Hacettepe Sağlık İdaresi Derg 2013;16:45-65. http://static.dergipark.org.tr/articledownload/imported/5000046470/5000043652.pdf?

21. Koç B, Terzi Y, Gül A. Üniversite öğrencilerinin iletişim becerileri ile kişilerarası problem çözme becerileri arasındaki ilişki. Uluslararası Türkçe Edebiyat Kültür Eğitim Derg 2015;4:369-90.

22. Shattell M. Nurse-patient interaction: a review of the literature. J Clin Nurs 2004;13:714-22. [CrossRef]

23. Tutuk A, AI D, Doğan $S$. Hemşirelik öğrencilerinin iletişim becerisi ve empati düzeylerinin belirlenmesi. C. Ü. Hemşirelik Yüksek Okulu Derg 2002;6:36-41. http://eskidergi.cumhuriyet.edu.tr/makale/608. pdf

24. Kumcağız H, Yılmaz M, Balcı Çelik $S$, Aydın Avcı İ. Hemşirelerin iletişim becerileri: Samsun ili örneği. Dicle Tıp Derg 2011;38:49-56. http://diclemedj.org/upload/sayi/13/Dicle\%20Med\%20J-01245.pdf

25. Temel E, Bahar A, Çuhadar D. Öğrenci hemşirelerin stresle baş etme tarzları ve depresyon düzeylerinin belirlenmesi. Fırat Sağlık Hizmetleri Derg 2007;2:107-18.

26. Karamanoğlu AY, Özer FG, Tuğcu A. Denizli ilindeki hastanelerin cerrahi kliniklerinde çalışan hemşirelerin mesleki profesyonelliklerinin değerlendirilmesi. Fırat Tıp Derg 2009;14:12-7. http://www.firattipdergisi.com/pdf/pdf_FTD_532.pdf

27. Ünsar S, Fındık ÜY, Sadırlı SK, Erol Ö, Ünsar S. Edirne sağlık yüksekokulu öğrencilerinin duygusal zekâ düzeyleri. Üniversite ve Toplum 2009;9:1-9.

28. Kaya ÖK, Şimşek Z, Kabalcıoğlu F, Dayı FF. Hemşirelerin mesleki imajlarını ve mesleği algılama durumlarını etkileyen faktörler. Hemşirelik Forumu Derg 2004;7:1-6. 